\title{
FARM TENANCY DISTRIBUTION AND TRENDS IN THE UNITED STATES
}

\author{
Howard A.Turner*
}

At the present time only half of the acreage that is in farms in the United States is farmed by its owners, the owners working personally with or without assistance of family and hired labor. The other. half is farmed by managers or by tenants who have to lease part if not all of the land they use. This was the situation in I935 and also in 1930 but a greater proportion of the acreage in farms was formerly owneroperated. In I900 almost three-fifths, $59 \%$, of the acreage in farms was farmed by its owners. These figures relative to acreage suggest that the tenure position of the American farmer is weak and is on the decline. This is a conclusion that may be confirmed by statistics of farms by number and kind, and also by what is known about the investment interests of farmers and others in farm real estate.

Farmers who owned all of the land they farmed were only $47.1 \%$ of all farmers in 1935 , whereas they were $52.2 \%$ of all farmers in 1920 and $55.8 \%$ of all farmers in 1900. Farmers who rented all of the land they farmed were $42.1 \%$ of all farmers in 1935, whereas they were $38.1 \%$ of all farmers in $1920,35.3 \%$ in $1900,25.6 \%$ in $1880 .{ }^{1}$ In I935 over half, $52.2 \%$ of the farmers rented some part if not all of the acreage they farmed. Some other farmers managed farms they did not own.

The younger a farmer is the more certainly must he farm as a tenant. In I930 about seven-eights, $86.5 \%$, of the farmers who were under 25 years of age were tenants or croppers. However, of farmers 45 to 54 years of age only about a third, $34.6 \%$ were tenants or croppers, and of farmers who were aged 65 years or over only about a sixth, $16.4 \%$, were tenants or croppers.

* B.S., Igr2, Massachusetts State College. Associate Agricultural Economist, Burcau of Agricultural Economics, United States Department of Agriculture, engaged chiefly in research in land tenure. Author of A Graphic Summary of Farm Tenure (U. S. Dept. of Agriculture, 1936) and numerous other publications of the Department of Agriculture relating to land tenure, rental contracts, and kindred subjects.

${ }^{2}$ Part of the increase in the rate of farm tenancy as indicated by these percentages occurred in connection with a fuller inclusion, in more recent years, of those counted as tenants and as farmers at all. The idea of regarding places worked by croppers as farms is still at variance with the way these places are commonly regarded in localities where much use is made of the cropper system of employing labor. However, thanks to the instructions and questions provided for census enumerators, beginning in 1920, cropper places have probably been pretty completely counted in as tenant farms. Inasmuch as the practice of giving employment to croppers has been confined almost wholly to the South, and largely to the cotton and tobacco growing parts of the South, only for such parts the South, the South as a whole, and the United States as a whole, is it necessary to accept with reservations comparisons showing the trend in farm tenancy. 
Only about a fourth of the farms of the country are operated by farmers who have neither rent or mortgage interest to pay. To achieve this position of relative independence even this comparatively small group of farmers find it necessary to confine themselves to farms below average in desirability judged by value. In I930 these farmers operated farms averaging only $\$ 6,129$ in value as compared with an average of $\$ 7,796$ for farms for the use of which operators had to pay interest, rent, or both interest and rent.

As compared with casual agricultural workers tenant farmers occupy a relatively sheltered position. To be a farm tenant is to have employment by the year and a house in which to live for the period of a year at least, a condition particularly advantageous to a family man. In times of economic stress the tenant farmers may even have less cause to worry than that class of owner-operators who are in debt with respect to their farms. In the five years between I930-I935 land values shrank very considerably, farms decreasing in value from an average of $\$ 48.5^{2}$ to an average of \$31.I6 per acre, a shrinkage of over a third, as much or more than the equity many owner farmers may have had in their farms in 1930.

Currently the financial interest of farmers in the real estate values of the farms they operate may be as much as two-fifths but can hardly be much more. The other three-fifths financial interest is held by other owners of real estate or by holders of farm mortgages. In rgro the financial interest of such other owners and mortgage holders was about half of the values represented by farm real estate and in 1890 such other parties had about a two-fifths financial interest.

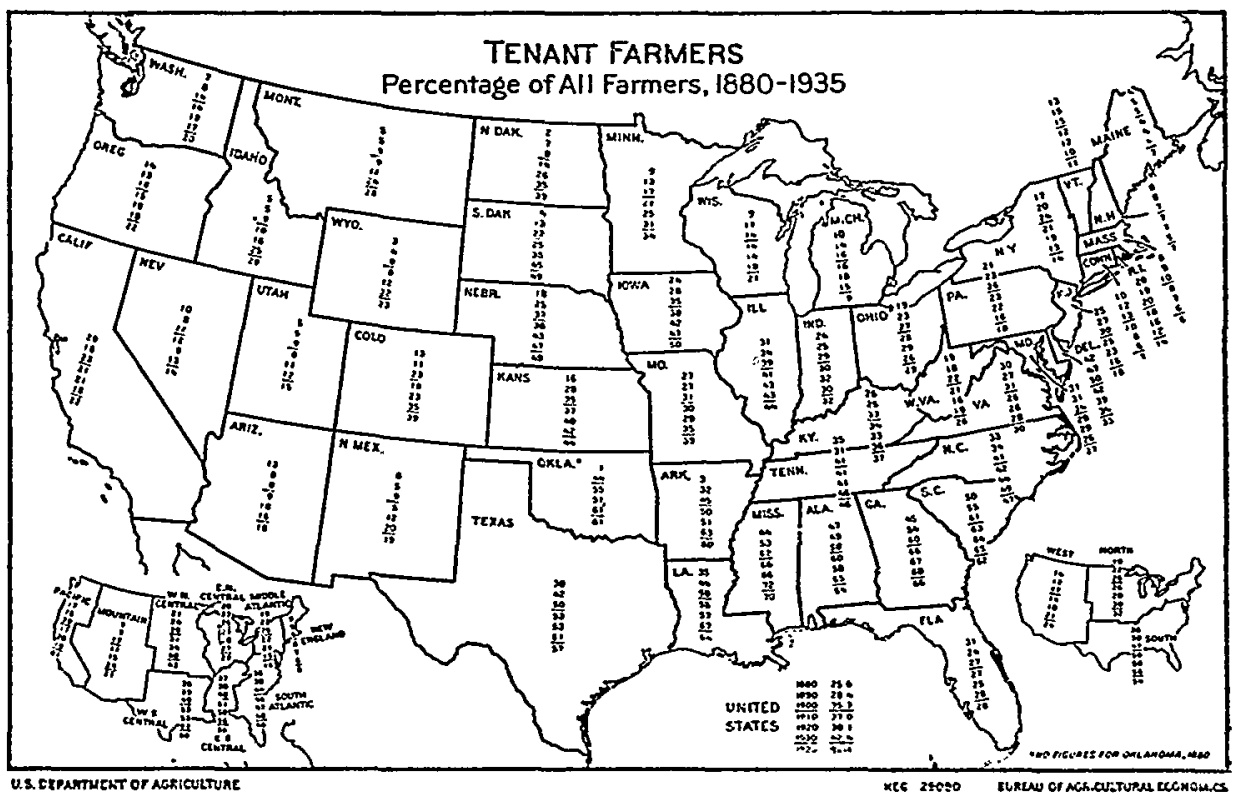




\section{Farm Tenancy in the South Compared With the Situation Elsewhere}

The South holds a place of major importance in the farm tenancy picture. So important is that position and so at variance with conditions elsewhere that consideration of farm tenure in the United States might well be made on the basis of contrasting situations, comparing the South with the rest of the country.

Over half, $53.5 \%$ in 1935 , of the farms in the 16 states of the South were operated by tenants who owned none of the land they farmed. Of the farms in the rest of the country only three-tenths, $30.5 \%$, were operated by tenants who owned none of the land they farmed. This striking difference in the rate of farm tenancy is related to differences with respect to a number of factors, among which color of farmer and type of farm should certainly be considered.

Of the farmers of the South nearly a fourth, $24 \%$ in 1935, are colored but only one percent of those who farm outside of the South are colored. This difference is of importance in relation to the national farm tenancy picture inasmuch as threefourths, $75.2 \%$ in 1935 , of the colored farmers of the country are tenants, whereas only three-eighths, $37.3 \%$ in 1935 , of the white farmers of the country are tenants. Of the white farmers of the 16 southern states $46 . x \%$ were tenants in 1935 , of the white farmers of the rest of the country $30.4 \%$ were tenants.

Type of farming is also of material weight in determining that the rate of tenancy in the South should be greatly different from that in the rest of the country. All but one percent of the cotton farms of 1930 were in the South and nearly three-fourths, $73 \%$, of the cotton farms were tenant-operated. ${ }^{2}$ Furthermore, a large proportion, half in I930, of the farms of the South are farms of the cotton type.

Because so many of the farms of the South are cotton farms and because most cotton farms are small places operated by tenants, a large proportion, slightly over half in $193^{\circ}$ and 1935 , of the farms of the South are under 50 acres in size, and the rate of tenancy on southern farms of that size is relatively high. In $1930,69 \%$ of the farms in the South containing less than 50 acres were tenant-operated as compared with $4 \mathrm{~T} \%$ of the farms containing 50 acres or more.

Although the rate of tenancy is higher in the South on farms of less than $5^{0}$ acres than on larger farms the situation is quite the reverse in the northern and western states. In 1930 only $17 \%$ of the farms of the North and West containing less than 50 acres were tenant-operated as compared with a $32 \%$ rate for farms containing 50 acres or more.

Of great significance as explaining why the rate of tenancy on farms in the United States increased from $35.3 \%$ in 1900 to $42.4 \%$ in 1930 is the change that occurred in the number of farms in the South of less than $5^{\circ}$ acres, farms created to make places for the increasing numbers of farmers interested in growing cotton and obliged to do so, for the most part, as tenants. Actually the rate of farm tenancy on farms of less than $5^{0}$ acres located in the South changed but little during these years; it was

\footnotetext{
2 Of farms other than farms of the cotton type $32 \%$ were tenant-operated in the United States in 1930.
} 
$68.4 \%$ in 1900 , and $69.4 \%$ in I930. But in the South the number of farms of less than $5^{\circ}$ acres increased from $1,149,536$ in 1900 to $x, 629,923$ in $193^{\circ}$. This was a greater numerical increase than occurred with respect to all farms, taking the country as a whole.

With no change in the rate of tenancy between 1900 and $193^{\circ}$ either in the South or the rest of the country on farms either less than 50 acres in size or larger the mere change in the number of farms of these two sizes would have increased farm tenancy in the United States from the $35.3 \%$ rate of Ig00 to a $37.8 \%$ rate in r930. Under the influence of this and of all other factors the rate of farm tenancy rose to $42.4 \%$ for the United States in $1930.0^{3}$

It is interesting to note that the decrease in the rate of farm tenancy for the United States as a whole from 42.4 in 1930 to $42.1 \%$ in 1935 occurred when the rate of tenancy for the South declined from 55.5 to $53.5 \%$ while the rate of tenancy on farms of the rest of the country increased from 28.5 in 1930 to $30.5 \%$ in 1935 . In view of the fact that the South has practically half the farms of the country, $50.2 \%$ in 1935, these changes might have cancelled each other but for the fact that there was but a six percent increase in numbers of farms in the five years in the South as compared with an eleven percent increase in the rest of the country. This difference increased the relative weight of the North and West, the section with the lower rate of tenancy, and so tended to lower the rate of tenancy for the country as a whole.

From the few facts so far stated it is obvious that changes in the rate of farm tenancy have been by no means uniform throughout the country or even in the same direction, also that the rate of farm tenancy is dependent to a very considerable degree upon such factors as the type and size of farms, differences in farmers and sectional difference. The blanket such differences must necessarily throw over the significance of averages for the country as a whole, or even over state and regional averages, makes it desirable to consider farm tenancy in as much detail as space and statistical information permit.

\section{Type of Farm}

As early as Ig00 over two-thirds, $67.6 \%$ of the farms on which cotton constituted the principal source of income were tenant-operated. This figure compares quite closely with the $72.7 \%$ tenancy on farms of the cotton type in 1930. The difference in the percentages is, indeed, only 5.I as compared with a 7.I increase in the percentage of tenancy on farms of the United States in general. However, only $18.7 \%$ of the farms of the country had cotton as a principal source of income in 1899 whereas in $193026.1 \%$ of the farms were of the cotton type. Thus the high tenancy rates prevalent on cotton farms came to affect a greater proportion of all

\footnotetext{
${ }^{8}$ Of the farms in the South of less than 50 acres $68.4 \%$ were tenant-operated in $1900,69.4 \%$ in 1930 . Of the farms of that size in the North and West $24 \%$ were tenant-operated in $1900,16.9 \%$ in 1930 . Of the farms in the South of 50 acres or more $30.2 \%$ were tenant-operated in $1900,41.4 \%$ in 1930 . Of the farms of the North and West of 50 acres or more $26 \%$ were tenant-operated in $1900,32.1 \%$ in 1930 .
} 
farms, tending thereby to raise the rate of tenancy on farms in general even faster than was the case on cotton farms in particular. ${ }^{4}$

Of farms from which sales of hay and grain afforded the principal source of income in $1899,39.3 \%$ were tenant-operated. At that time $23 \%$ of the farms were hay and grain farms. Farms of the cash grain type are not quite a comparable group, but it is interesting to note that in 1930 on the $7.2 \%$ of the farms of the country that were of the cash grain type over half, $5 x .2 \%$, were tenant-operated. The lessee interest in land devoted to cash grain types of farming is undoubtedly considerably more than half because the renting of acreage by owner farmers as a means of increasing their operations is particularly common in cash grain areas.

The 1900 census reported $6.2 \%$ of the farms to have dairy produce, $1.4 \%$ to have fruit, and $2.7 \%$ to have vegetables as the principal source of income. The rates of tenancy for 1900 were $23.3 \%$ for the dairy produce farms, $16.4 \%$ for the fruit and $30.4 \%$ for the vegetable farms. In $19309.6 \%$ of the farms of the country were of the dairy type, $2.2 \%$ were fruit farms, $1.3 \%$ were truck farms. Of the dairy farms $21.4 \%$ were tenant-operated, of the fruit farms $\times 1.4 \%$, decreases from the rates of tenancy prevalent on these types of farms in 1900 . The rate of tenancy in 1930 on truck farms was $32.8 \%$, or slightly more than the rate on vegetable farms in 1900 .

In 1900 the rate of tenancy on tobacco farms was $47.8 \%$. On crop specialty farms the 1930 rate of tenancy was $46.7 \%$ : These two percentages are not strictly comparable inasmuch as not all crop specialty farms have tobacco as their specialty, some are sugar farms, beet or cane, others raise potatoes, or peanuts, or beans, etc. Altogether $6.9 \%$ of all farms were classified as crop specialty farms in 1930, with tobacco farms the largest single group. Between 1900 and 1930 the number of tobacco farms increased very considerably with the expansion of tobacco into new areas. In $1900,1.9 \%$ of the farms had tobacco as a principal source of income.

Livestock apart from dairy produce afforded most of the income in 1899 on a considerable proportion, 27.3\%, of all farms and of these livestock farms $20.3 \%$ were tenant-operated. In 1930 animal-specialty, stock ranches, poultry farms and general farms together constituted $28 \%$ of all farms, and the rate of tenancy for the combined group was $26.7 \%$. Assuming these 1930 groups as combined to be comparable with the livestock farms of 1899 , and they constituted quite the same proportion of all farms, the rate of tenancy has apparently increased very considerably on them. The 1930 rate of tenancy was $26.9 \%$ on general farms, $32.7 \%$ on animalspecialty farms, $15.4 \%$ on stock ranches and $12.7 \%$ on poultry farms.

Farms of the self-sufficing type were $7.9 \%$ of all farms in 1930 and of these farms over a fourth, $26.6 \%$, were tenant-operated. In Igoo these farms were not considered as a separate type but were included in a miscellaneous group constituting

\footnotetext{
-In 1900 the rate of tenancy on farms on which cotton did not constitute the principal source of income was $27.9 \%$. In 1930 tenants operated $31.7 \%$ of the farms that were not of the cotton type. Consequently the increase in the percent of tenancy on farms not of the cotton type was less than it was on farms of the cotton type.
} 
I8.5\% of all farms. Of these so-called miscellaneous farms $24.9 \%$ were tenantoperated.

\section{Value of Farm in Relation to Status of Operator}

The value of farms is usually related to the income to be derived from them. Thus differences in the value of farms are suggestive of somewhat corresponding differences in the incomes and standards of living of farmers. If the inference is a valid one, tenants in certain Corn Belt states may have an income about ten times as great, on the average, as tenants in certain southern states, with all that may mean in terms of standards of living and opportunities to save money. For in 1935 the farms operated by tenants in Illinois, in Iowa and in Nebraska averaged over $\$ 10,000$ in value whereas the tenant farms of Alabama and Mississippi had average values of less than $\$ 1,000$.

Subject to the criticism that dwelling values as obtained by census enumerators can be no more than roughly approximate, statistics of the I930 census on the value of dwellings occupied by farmers throw further light on the standards of living of farmers. At that time most farm dwellings of the South were given a value of less than $\$ 500$, and in the South two-thirds of the farms with dwellings of less than $\$ 500$ were occupied by tenants. Of the comparatively few southern farmers who enjoyed the occupancy of farms with dwellings worth $\$ 1000$ or more in value less than a fourth were tenants. In the North-Central states, on the other hand, on but a small proportion of the farms were the dwellings valued at less than $\$ 500$, a greater number of farms had dwellings worth $\$ 3,000$ or more. The rate of tenancy ranged between $37 \%$ on North-Central state farms with dwellings worth less than $\$ 500$ to $25 \%$ on farms with dwellings worth $\$ 3,000$ or more.

In the Corn Belt, and seemingly in most of the country outside of the South, there is a rather close relationship between the value of a farm and the probabilities that it will be operated as a tenant farm. In the Corn Belt the percentage of farms operated by tenants rises with the average value of farms, counties compared. Farm values affect the rate of tenancy scarcely at all in counties of the Cotton Belt. ${ }^{5}$

The rate of tenancy in the counties of the North and West may be largely determined by the distribution of farms by value. In I925 less than a fourth of the farms of Centre County, Pennsylvania, were valued at \$10,000 so that the average rate of tenancy was determined more by the $27 \%$ rate on the large proportion of farms worth less than $\$ 10,000$ than by the $59 \%$ rate on the small proportion of farms worth $\$ 10,000$ or more. The rate of tenancy in Dickinson County, Iowa, on the other hand was very largely determined by the $63 \%$ rate on the great number of farms, nearly nine-tenths of all, that were valued at \$10,000 or more and only to a minor degree by the $44 \%$ rate on the few farms worth less than $\$$ ro,000. Of all farms in Centre County, Pennsylvania, 33.5\% were tenant-operated in 1925 as compared with $60.9 \%$ of all farms in Dickinson County, Iowa.

'Turner, A Graphic Summary of Farm Tenure (U. S. Dep't of Agr. 1936) Misc. Pub. No. 261, p. 42. 


\section{Variations in Farm Tenure Within the South}

For purposes of considering differences in farm tenure within the South it is of advantage to consider the Cotton Belt counties as apart from the rest of the 16 southern states. The Cotton Belt part of the 16 southern states contained over half, $53 \%$, of the $3,421,923$ farms of the South in 1935 . The Cotton Belt part contained $46 \%$ of the white farmers of the South, $56 \%$ of the white farmers who farmed as tenants, $59 \%$ of the white tenants who farmed as croppers. It had $73 \%$ of the colored farmers of the South, $80 \%$ of the colored farmers who were tenants, $82 \%$ of the colored tenants who were croppers.

In the South the rate of tenancy among white farmers was $56 \%$ in the Cotton Belt as compared with $38 \%$ outside, while among colored farmers it was $84 \%$ in the Cotton Belt as compared with $59 \%$ outside. In the South $30 \%$ of the white tenants within the Cotton Belt were of cropper status as compared with $27 \%$ outside the Cotton Belt. As for the colored tenants of the South $61 \%$ were croppers in the Cotton Belt as compared with $50 \%$ outside of it.

Ignoring color of farmer it appears that within the Cotton Belt part of the South $65 \%$ of the farmers were tenants in 1935 and that croppers represented $43 \%$ of the tenants or $28 \%$ of the total number of farmers, whereas in the rest of the South $41 \%$ of the farmers were tenants, croppers were $32 \%$ of the tenants or $13 \%$ of the farmers.

No doubt many who regard themselves as well informed think that a majority of the tenant farmers of the Cotton Belt of the South are colored farmers. That, indeed, was the situation in 1920 and in prior years. However, in 1925, in 1930 and again in 1935 a majority of the tenant farmers of the Cotton Belt of the South have been whites. It is true that in parts of the Cotton Belt most of the tenant farmers are of the colored race; that was the case in 1935 in the following sub-regions of the Cotton Belt of the South: the southern Piedmont, the eastern Coastal Plain and Sand Hills, the Black-Belt of Mississippi and Alabama, the brown loam area of Mississippi and Tennessee, and the Mississippi and Red River Delta counties, of Tennessee, Mississippi, Arkansas and Louisiana. In the above sub-regions and in those listed as follows, colored tenants who were croppers out-numbered white croppers: the clay hills and rolling uplands of Mississippi and Alabama, the Piney Woods of Northeast Texas and the area comprising southwestern Arkansas and Northern Louisiana. In the remaining sub-regions of the Cotton Belt not only were white tenants more numerous than colored but white tenants who were croppers out-numbered the colored croppers. These sub-regions include the river and limestone valley counties along the Tennessee, the northern Piedmont, the Gulf Coast Plain, the cotton-self-sufficiency area of the Piney Woods, the Post Oak strip of the upper Coastal Prairie, the Black Waxy Prairie of Texas, Arkansas river valley and uplands, the cotton-general farming area of Oklahoma and Texas, and the large scale farming area of Oklahoma and Texas. 
In most of the major sub-regions of the Cotton Belt of the South the percentage of tenancy among white farmers declined somewhat between I930 and r935 but in no case was this decline sufficient to bring the 1930 percentage down to the I9ro or 1920 figure. Even in I935 over three-fifths of the white farmers were tenants in the group of counties between the Yazoo and Mississippi rivers, also in the other inland "delta" counties, in the Black Waxy prairie of Texas and in the large-scale farming area of Oklahoma and Texas. Only in the semi-self-sufficing Piney Woods, the clay hills and rolling uplands of Mississippi and Alabama, and in the southwestern Arkansas-northern-Louisiana sub-regions of the Cotton Belt were less than half of the white farmer tenants in 1935 .

Between 1910 and $193^{\circ}$ the increase in percentage of tenancy among white farmers in the sub-regions of the South's Cotton Belt generally occurred in connection with an increase in the number of white farmers. This is the sort of thing that might be expected where opportunities to farm attract men who, for the most part, are without the means to own their farms. The decrease in the rate of tenancy among white farmers between $193^{\circ}$ and 1935 was accompanied by an increase in the number of white tenants and in the number of whites who were owners. Consequently this $1930-35$ decrease in the rate of tenancy cannot be construed to have been the result of a decrease in the amount of employment available to whites as tenant farmers in the Cotton Belt.

In each of the major sub-regions of the Cotton Belt the percentage of white tenants farming as croppers was higher in I930 than in I920 but lower in I935 than in 1930. In a few instances the I935 percentage was carried down below the r920 figure.

In the case of the colored farmers of the Cotton Belt these decreased in numbers between I930 and I935 in such a way as to cut the number of colored tenants furnishing their own mules relatively more than the number of colored croppers. As the number of colored owners was reduced somewhat at the same time the slight reduction in the rate of tenancy among these colored farmers in no wise represented a real gain. Of greater significance was the increase in proportion of colored tenants in the Cotton Belt working as croppers; it was $61 \%$ of these in 1935 as compared with $5^{6}$ in 1930. Among white tenants, by contrast, the reduction in numbers of croppers was more than offset by an increase in number of white tenants furnishing their own mules. So far did these changes go that only $30 \%$ of the white tenants of the Cotton Belt farmed as croppers in 1935 whereas $38 \%$ had done so in 1930 .

Among colored as among white farmers of the Cotton Belt of the South the rate of tenancy was at a comparatively high level in $193^{\circ}$ and at the time a comparatively high proportion of the colored tenants worked as croppers. Of the several major sub-regions of the cotton South the percentage of tenancy among colored farmers is highest in the region of Mississippi between the Yazoo and Mississippi rivers. Here also the greatest proportion of colored tenants work as croppers. In 
this sub-region $97 \%$ of the colored farmers were tenants in 1930 and again in 1935. In it, of the colored tenant farmers $62 \%$ worked as croppers in $1920,76 \%$ in 1925 , $76 \%$ in 1930 and $85 \%$ in 1935 . Nowhere else in the South do so large a proportion of the colored tenants farm as croppers.

The $193^{\circ}$ Census of Agriculture published statistics on the number of plantations with given numbers of croppers in a few of the most pronounced plantation counties of the cotton South. ${ }^{8}$ In $193^{\circ}$ the 36,343 farm units in the three Delta counties of Bolivar, Quitman and Sunflower in Mississippi included I84 units operated by managers, 1,676 units operated by owners, full or part, 3,362 units operated by cash tenants, 5,775 units operated by share tenants and 25,346 units operated by croppers. Most of the croppers, about $85 \%$, were colored. There were just about two thousand, 2,00I, plantations with three or more croppers. Most croppers, perhaps about $95 \%$, must have been on these places as there were 1,477 plantations with at least 5 croppers, 879 plantations with at least Io croppers, $35^{6}$ plantations with at least 20 croppers, II7 plantations with at least 50 croppers and 25 plantations with at least I0o croppers. Home farms were operated in connection with 86I of the 2,00x plantations with 3 or more croppers and as the number of croppers increased there was an increasing tendency to have a home farm in connection with the plantation. Owners, full or part, who operated a home farm and had three or more tenants as well numbered 638. In addition 344 owners, full or part, operated a home farm and had I or 2 tenants while 694 owners, full or part, operated places on which they had no tenants.

\section{Age and Color of Farmer in Relation to Tenure}

The widespread use in the South of the cropper system makes it comparatively easy for a man with little or no capital to be a tenant farmer there with the status of a cropper. In the South it is quite easy to become a cropper at the age of marriage and among those who have a prospect of becoming croppers marriage is seldom deferred for the purpose of accumulating capital. Elsewhere in the country opportunities open to men without considerable capital to become tenant farmers are comparatively rare. Thus there is no great point in combining statistics on age of farmer in relation to tenure status to consider the situation in the country as a whole. Differences between the white and colored farmers of the South with respect to the proportion occupying the status of croppers make it desirable to consider these races separately in comparisons of tenure status in relation to age.

A higher percentage of farmers in each age group were tenants in 1930 than in rgro and this holds true for white farmers of the South, colored farmers of the South, and farmers of the rest of the country considered regardless of color. Perhaps no less significant is the fact that there has been a reduction in the proportion of young farmers to all farmers. For example in the 32 states of the North and West

'Elliott, Types of Farming in the United States (U. S. Dep't of Commerce, 1933) 180-181. 
$24 \%$ of the farmers reporting their age in 1910 were under 35 years of age but only $18 \%$ were that young in 1930 .

That most colored farmers may not expect to become owner farmers is indicated by the fact that even of those 65 years and over $56 \%$ were tenants in 1930 in the South. Of the white farmers of the South that old, only $19 \%$ were tenants in 1930 , and of the farmers 65 years or over in the rest of the country only $9 \%$ were tenants.

There were more farmers between the age of 35 and 45 than in any other ten year age group of older or younger farmers. Of these 35 to 45 year old farmers, $82 \%$ were tenants in 1930 among the colored of the South, $49 \%$ were tenants among the whites of the South and $37 \%$ were tenants among farmers in the rest of the country. Comparable percentages for rgro were, respectively 77,38 and 28 .

In 1930 there were, in the South, 529,000 white and 186,000 colored farm operators who were aged 35 to 45 years; in the rest of the country were 738,000 farm operators that old. Assuming that as these grow older they are replaced by enough younger men to keep their numbers constant and that these younger men were working on farms in 1930, there must have been, making no allowance for death among younger men so employed, on farms of the South at least 97,000 whites and 18,000 colored aged 25 to 35 and 337,000 whites and 87,000 colored under the age of 25 who, in r930, were not already farm operators. On farms in the rest of the country there must have been at least 289,000 between the ages of 25 and 35 and 657,000 between the ages of 15 to 25 who were not farm operators in $193^{\circ}$.

The 404,000 total of workers without tenure aged 25 to 34 in 1930 required to supplement the $1,049,000$ farm operators aged 25 to 34 if the $1,453,000$ operators aged 35 to 44 are to be kept constant in number as older ones leave the age group with increasing age, is a very minimum, inasmuch as the number makes no allowance for death. It may be taken as some measure of the minimum number of agricultural workers of the age competent enough to be farm tenants but hardly as any measure of the actual number of agricultural workers aged 25 to 34 .

Tenant farmers have an average age of about ten years less than owner farmers and consequently more of their children are of a dependent age. In I925 the population on owner-operated farms averaged 4.5 individuals including one child under the age of ro years. By comparison the population on tenant-operated farms averaged 4.6 individuals including 1.4 individuals under the age of to years. The significance of this distribution of the population on farms was that $46.4 \%$ of the farm children under to years of age were on tenant farms although these farms had only $36.3 \%$ of the farm population Io years of age and over. Put another way, $30.5 \%$ of the population on tenant farms was under the age of ro years as compared with $22.3 \%$ of the population on owner-operated farms. The reader need not be reminded that differences such as these must make a material difference in the standards of living that can be maintained on tẹnant as compared with owner-operated farms. 